\title{
Model Pengembangan Pelayanan Administrasi Terpadu Kecamatan (PATEN) Berbasis Governansi Digital Berkelanjutan
}

\author{
Raniasa Putra1', Muhammad Yusuf Abror², Januar Eko Aryansah¹, Khairunnas², Azhar², \\ Kiagus Muhammad Sobri', Hoirun Nisyak² \\ 'Departemen Ilmu Administrasi Publik, ²Departemen Ilmu Hubungan Internasional, Fakultas Ilmu Sosial dan Ilmu \\ Politik, Universitas Sriwijaya \\ Jl. Masjid Al Gazali, Bukit Lama, Palembang, 30128, Indonesia
}

\begin{abstract}
ARTICLE INFO
Received: 2020-12-10

Revised: 2021-01-18

Accepted: 2021-03-23

Keywords:

Administration, Digitization, Good governance, Smart city, Website

\section{ABSTRACT}

The article explains District Integrated Administration Service Development Model (PATEN) as part of digital public service and transparancy to the community This is also a competitive model of Rambang Kapak Tengah Regency. The digital feature is reflected on the website development that integrated with surrounding villages. The aim of digital public service is to give simplicity of service to the people. Furthermore, the principle of smart city is transforming outdated method to industry 4.0 approach. Hence the innovation can be started by developing website on Rambang Kapak Tengah Regency. The study makes use of 2 methodology; observation directly to the site to gain potential data and desk study to deepening the analysis of using digital platform on government administrative. The implementation of digital platform as one of smart city's criteria will provide easier access for people to get information and at the same time deliver accurate information.
\end{abstract}

(C)2021 Published by University of Merdeka Malang. This is an open access article distributed under the CC BY-SA 4.0 license (https://creativecommons.org/licenses/by-sa/4.0/)

How to cite: Putra, R., Abror, M. Y., Aryansah, J. E., Khairunnas, K., Azhar, A., Sobri, K. M., \& Nisyak, H. (2021). Model Pengembangan Pelayanan Administrasi Terpadu Kecamatan (PATEN) Berbasis Governansi Digital Berkelanjutan. Abdimas: Jurnal Pengabdian Masyarakat Universitas Merdeka Malang, 6(2), 290-304. https://doi.org/10.26905/abdimas.v6i2.5149

\section{PENDAHULUAN}

Sistem administrasi konvensional saat ini dirasa kurang efektif dan efisien. Jika masyarakat butuh informasi terkait dengan kebutuhan administrasi saat ini harus menuju ke kecamatan dan ini dianggap sebagai metode yang sudah usang. Padahal dengan penerapan digitalisasi pelayanan administrasi dalam bentuk e-government, hal-hal tersebut dapat dipermudah dengan hanya membuat website layanan 
kecamatan. Website atau situs juga dapat diartikan sebagai kumpulan halaman yang menampilkan informasi data teks, data gambar diam atau gerak, data animasi, suara, video dan atau gabungan dari semuanya, baik yang bersifat statis maupun dinamis yang membentuk satu rangkaian bangunan yang saling terkait di mana masing-masing dihubungkan dengan jaringan-jaringan halaman (hyperlink) (Nurmi, 2017). Dapat diartikan bahwa website merupakan kumpulan halaman yang saling terhubung satu salam lainnya untuk memberikan berbagai informasi kepada pengguna laman.

Konsep digitalisasi dan good governance menjadi landasan berpikir dalam pengabdian ini sehingga akan mempermudah proses penerapan inovasi pembuatan website di Kecamatan Rambang Kapak Tengah, Kota Prabumulih. Kecamatan Rambang Kapak Tengah merupakan kecamatan yang memiliki akses cukup jauh dari pusat Kota Prabumulih. Tentu hal ini dapat mempersulit warga yang ingin mengurus pelayanan administrasi. Maka pelayanan berbasis digital ini menjadi salah satu jalan keluar yang memungkinkan saat ini. Digitalisasi merupakan hal yang memudahkan pengaksesan informasi secara real time yang dapat diakses melalui teknologi informasi (Aji, 2016). Dengan adanya digitalisasi di sektor pemerintahan maka akan memberikan kemudahan kepada masyarakat dalam mengakses informasi.

Pelaksanaan digitalisasi pelayanan masyarakat ini juga mendukung konsep smart city yang diusung oleh Kota Prabumulih sehingga terdapat korelasi dengan pengabdian kepada masyarakat FISIP Universitas Sriwijaya. Smart city sendiri secara sederhana dimaknai sebagai kota pintar yang dapat memberikan kualitas hidup yang baik dan memberikan kenyamanan bagi masyarakat kota (Hasibuan \& Sulaiman, 2019). Maka smart city menjadi penting untuk dapat diterapkan agar dapat memberikan kenyamanan dan keamanan bagi masyarakat kotanya. Jika dijabarkan lebih lanjut, smart city dapat dilihat ke dalam 7 dimensi, yaitu: (1) Smart economy; (2) Smart people; (3) Smart governance; (4) Smart mobility; (5) Smart environment; (6) Smart living; dan (7) Smart disaster management. (Faidati \& Khozin, 2018)

Dari tujuh dimensi di atas, penulis fokus pada smart governance yang diterapkan pada Kecamatan Rambang Kapak Tengah, Kota Prabumulih. Adapun smart governance yang diusung oleh Tim Pengabdian Kepada Masyarakat Universitas Sriwijaya yaitu tim membuatkan website kecamatan agar proses layanan administrasi dan keterbukaan informasi dapat berjalan dengan baik dan terbuka. Berbagai faktor membuat tim pengabdian mengedepankan inovasi karya dalam bentuk website kecamatan untuk mempermudah proses administrasi antara pemerintah, masyarakat, pemerintahan lainnya, pekerja pemerintah, dan pebisnis yang memiliki kepentingan di Kecamatan Rambang Kapak Tengah, Kota Prabumulih.

\section{METODE}

Metode yang digunakan dalam kegiatan pengabdian kepada masyarakat ini terbagi menjadi empat metode yang dijelaskan dalam Gambar 1 . 
ABDIMAS: Jurnal Pengabdian Masyarakat Universitas Merdeka Malang

Volume 6, No. 2, May 2021: 290-304

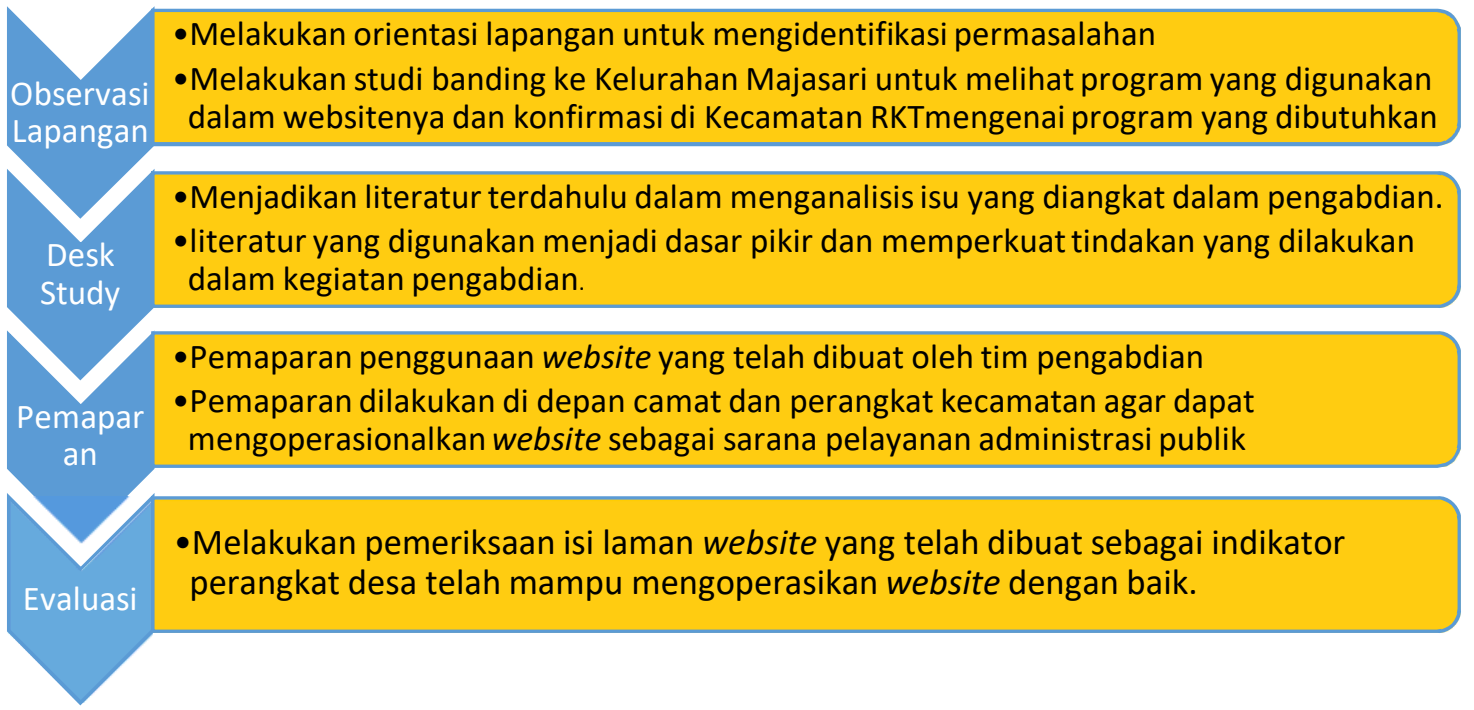

Gambar 1. Kerangka pembahasan

\section{Observasi lapangan}

Observasi lapangan bertujuan untuk mengumpulkan data primer sebagai data utama yang dipergunakan sebagai identifikasi permasalahan di lapangan. Observasi merupakan proses pengamatan sistematis dari aktivitas manusia dan pengaturan fisik dimana kegiatan tersebut berlangsung secara terus-menerus dari lokus aktivitas bersifat alami untuk menghasilkan fakta (Hasanah, 2016). Data yang didapat dari pengamatan tersebut kemudian dikelola menjadi bentuk solusi yang dapat memberikan jawaban dari permasalahan yang ada.

Adapun bentuk observasi lapangan yang dilakukan adalah dengan cara mengunjungi Kecamatan Rambang Kapak Tengah (RKT) dan Kelurahan Majasari. Kecamatan Rambang Kapak Tengah ini merupakan kecamatan yang menjadi fokus pengabdian, sedangkan Kelurahan Majasari merupakan kelurahan yang telah menggunakan sistem layanan administrasi berbasis digital dalam bentuk website kelurahan. Sebelum menuju Kecamatan RKT, penulis melakukan studi banding di Kelurahan Majasari mengenai apa saja jenis pelayanan di sana dan kendala apa saja yang ditemukan selama menggunakan website serta apa dampaknya bagi pelayanan administrasi kelurahan. Dengan demikian, penulis dapat mengidentifikasi langkah selanjutnya untuk membuat kerangka website Kecamatan RKT. Setelah studi banding dilaksanakan, penulis melakukan kunjungan ke Kecamatan RKT, yaitu melakukan identifikasi pelayanan apa saja yang dibutuhkan warga di kecamatan dan informasi apa saja yang ingin disampaikan kepada publik melalui media website.

Setelah semua identifikasi masalah selesai dilakukan, penulis mulai membuat website dan melakukan sosialisasi penggunaan website di Kecamatan RKT kepada perangkat kecamatan dan kelurahan/desa. Tujuannya adalah agar perangkat tersebut dapat menyampaikan informasi mengenai website kecamatan 
kepada warga dan dapat memanfaatkannya dengan maksimal. Sehingga potensi warga yang berada di Kecamatan RKT dapat dipromosikan ke pasar yang lebih luas. Maka potensi pergerakan ekonomi dapat meningkat serta pelayanan administrasi dapat maksimal.

\section{Desk study}

Metode desk study yaitu artikel ini menggunakan sumber sekunder untuk melengkapi dan mendukung isi artikel ini. Seperti misalnya, menggunakan konsep sebagai dasar pikir yang didapatkan dari jurnal.

\section{Pemaparan}

Pemaparan penggunaan website yang dilakukan oleh tim pengabdian masyarakat FISIP Unsri langsung ditujukan kepada perangkat kecamatan. Hal ini dikarenakan perangkat kecamatan yang akan menjalankan sistem dari website serta aktor yang akan mengelola informasi administrasi maupun informasi lainnya.

\section{Evaluasi}

Program pengabdian ini bertujuan untuk melakukan inovasi dalam bentuk digitalisasi dalam administrasi dan informasi dari kecamatan kepada masyarakat. Maka tingkat keberhasilan diukur dari kemampuan dan kecakapan perangkat kecamatan dalam mengunggah informasi dan menyampaikan prosedur administrasi layanan kepada masyarakat.

\section{HASIL DAN PEMBAHASAN}

\section{Hasil}

Pada bagian hasil berisi kegiatan yang dilakukan pada masa proses pengabdian kepada masyarakat sehingga memiliki gambaran yang jelas mengenai apa yang sudah dilakukan selama dalam proses kegiatan pengabdian. Dalam proses penguatan pengumpulan data untuk membuat inovasi berupa website kecamatan dibutuhkan lima tahapan pelaksanaan.

\section{Observasi lapangan}

Tahapan awal pengabdian dilakukan dengan kunjungan ke Kelurahan Majasari untuk melihat dan observasi website kelurahan yang sebelumnya sudah ada sehingga tim pengabdian memiliki gambaran yang lebih terstruktur mengenai substansi yang dibutuhkan masyarakat. Setelah selesai melakukan observasi di Kelurahan Majasari, tim pengabdian melanjutkan ke Kecamatan Rambang Kapak Tengah sebagai tempat tujuan dari pengabdian. Di kecamatan ini dilakukan diskusi mengenai apa yang dibutuhkan oleh kecamatan dan masyarakat yang dapat diaplikasikan ke dalam bentuk website. 
ABDIMAS: Jurnal Pengabdian Masyarakat Universitas Merdeka Malang Volume 6, No. 2, May 2021: 290-304
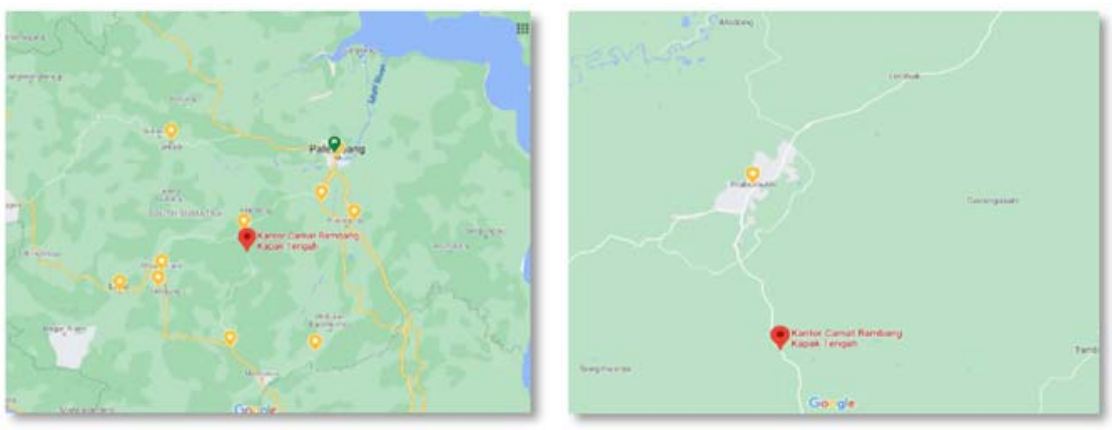

Gambar 2. Peta Kecamatan Rambang Kapak Tengah

Peta lokasi Kecamatan Rambang Kapak Tengah berada di Provinsi Sumatera Selatan, Kota Prabumulih. Kecamatan ini merupakan kecamatan yang terletak di pinggir kota berbatasan dekat dengan Kabupaten Muaran Enim. Adapun jarak Kecamatan Rambang Kapak Tengah dari Palembang dapat di tempuh selama sekitar 3 jam perjalanan darat menggunakan mobil pribadi.
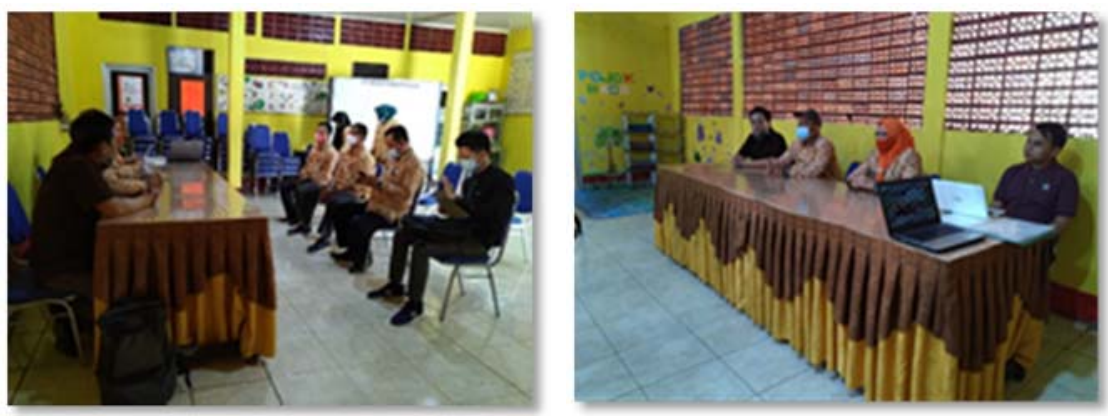

Gambar 3. Rapat dengar pendapat di Kelurahan Majasari bersama Lurah dan Camat Rambang Kapak Tengah beserta perangkat

Gambar 3 menjelaskan mengenai kegiatan rapat dengar pendapat untuk mengidentifikasi masalah pelayanan publik di Kecamatan Rambang Kapak Tengah. Adapun tempat pelaksanan rapat berlokasi di Kelurahan Majasari karena kelurahan ini telah terlebih dahulu melakukan pelayanan publik berbasis daring melalui website. Program yang dilakukan di Kelurahan Majasari dapat diaplikasikan juga di Kecamatan Rambang Kapak Tengah. Maka, Camat Rambang Kapak Tengah beserta perangkat merumuskan program apa yang dibutuhkan oleh kecamatan.

\section{Perancangan website}

Setelah didapatkan informasi yang cukup dari observasi lapangan seperti data kelurahan/desa di wilayah kecamatan, prosedur pelayanan administrasi, berita terkini kegiatan masyarakat, maka pihak tim pengabdian melakukan rancangan pembuatan website serta isi menu yang dibutuhkan dalam rangka pelayanan kepada masyarakat. Adapun proses pembuatan ini dilakukan oleh pihak tim pengabdian 
masyarakat dengan pihak pengembang Begun Technology agar website yang dibuat lebih profesional dan memiliki layout antar-muka yang bagus.

Dalam prosesnya website yang sudah jadi terus dimodifikasi sesuai dengan kebutuhan yang didiskusikan dengan pihak kecamatan. Setelah dianggap sesuai oleh pihak kecamatan, tim pengabdian melatih operator kecamatan untuk mengedit laman website Kecamatan Rambang Kapak Tengah.

\section{Pemaparan penggunaan website}

Proses perancangan dan pembuatan website telah selesai dengan pihak pengembang maka dilakukan pemaparan kepada pihak perangkat kecamatan yang ada di Kecamatan Rambang Kapak Tengah. Pemaparan yang dilakukan yaitu memberikan cara mengunggah berita atau informasi pelayanan adminstrasi kepada masyarakat. Menjelaskan fitur-fitur yang ada di dalam website sehingga perangkat kecamatan dapat memahami penggunaannya.

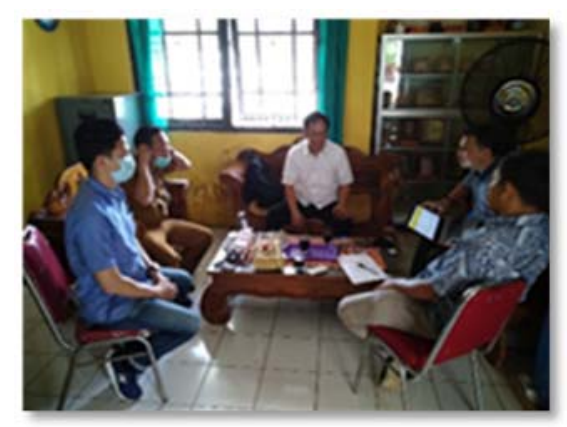

Gambar 4. Penjelasan teknis penggunaan website kepada pihak kecamatan

Gambar di atas menerangkan bahwa sedang adanya diskusi mengenai penggunaan website secara teknis dari tim pengabdian kepada pihak kecamatan. Hal ini dimaksudkan agar perangkat kecamatan dapat mengoperasikan website kecamatan yang telah dibentuk oleh tim pengabdian dengan lancar. Maka, potensi pelayanan publik yang maksimal dapat tercapai sesuai dengan prinsip PATEN.

\section{Display}

Memperlihatkan layout antar muka website kepada perangkat desa agar memahami lebih lanjut penerapan penggunaan website dan tujuannya agar website dapat dilakukan secara berkesinambungan hingga selanjutnya.

\section{Penutupan}

Pelaksanaan penyampaian teknis penggunaan website sebagai sarana untuk memahami materi telah dilaksanakan di kantor Kecamatan Rambang Kapak Tengah bersama camat dan perangkat. 
ABDIMAS: Jurnal Pengabdian Masyarakat Universitas Merdeka Malang

Volume 6, No. 2, May 2021: 290-304

\section{Materi kegiatan}

Materi kegiatan pengabdian masyarakat ini menggunakan landasan berpikir dari jurnal mengenai inovasi pelayanan publik, governansi digital, dan Pelayanan Administrasi Terpadu Kecamatan (PATEN). Narasi dalam diskusi bersama pihak kelurahan dan kecamatan yang telah dilakukan yaitu membicarakan mengenai pelayanan publik yang sesuai standar, teknis penggunaan website, kebijakan pelayanan publik, respon masyarakat mengenai adanya e-government.

\section{Inovasi pelayanan publik}

Inovasi dalam pelayanan publik menjadi hal yang penting dan memberikan kemudahan dalam pelayanan administrasi. Jika dilihat dalam beberapa institusi di Indonesia, pelayanan publik kurang begitu memuaskan dan terkesan usang karena berdampak pada hasil yang kurang maksimal terhadap masyarakat. Dibutuhkan inovasi pelayanan publik agar aspek ekonomi, sosial, politik, budaya, dan sebagainya berjalan dengan (Yanuar, 2019). Sehingga masalah dalam proses penyelenggaran pelayanan publik merupakan isu yang selalu menarik untuk menjadi bahan kajian di dunia perguruan tingggi dan di tataran praktis.

Pada dasarnya, pelayanan publik menjadi penting karena merupakan proses suatu organisasi untuk memenuhi kebutuhan. Beragam macam bentuk-bentuk pelayanan terhadap publik diantaranya adalah pelayanan jasa, barang, dan administrasi. Sehingga jika dilihat dari inti bisnis dari pelayanan publik ini adalah adanya orientasi pada proses pelayanan yang maksimal yaitu produksi dari layanan dan produksi layanan tadi dapat diterima dengan baik kepada konsumen/masyarakat. Ini menjadi penting karena poduksi layanan yang berkualitas akan membuat konsumen merasa puas. Maka inovasi pelayanan publik harus selalu ditingkatkan untuk memberikan pelayanan yang maksimal sehingga kinerja dari pelayan publik tidak dianggap biasa-biasa saja atau cenderung buruk.

Kondisi pelayanan publik yang belum baik di tengah banyaknya tuntutan dari masyarakat agar pemerintah melakukan upaya terus-menerus dalam memberikan layanan yang terbaik kepada masyarakat membuat pemerintah harus segera mengakomodirnya. Salah satu tantangan dalam pelayanan publik yang paling penting untuk direspon oleh pemerintah saat ini ialah bagaimana pemerintah mampu berinovasi memberikan pelayanan agar masyarakat semakin mudah untuk mengakses pelayanan yang disediakan oleh pemerintah sebagai bentuk tanggungjawab negara kepada masyarakat. Inovasi pelayanan publik adalah suatu keharusan bagi pemerintah pusat maupun pemerintah daerah guna untuk mengimplementasikan pelaksanaan desentralisasi, yaitu mengupayakan peningkatan kesejahteraan, kemakmuran dan kemandirian bagi masyarakat dan daerahnya (Yanuar, 2019).

Dengan adanya tuntutan perbaikan pelayanan publik dimana ekspektasi atau harapan masyarakat semakin tinggi kepada penyelenggara layanan perlu dilakukan reformasi pelayanan publik, yaitu dengan mengembalikan dan mendudukkan makna "pelayan" dan "dilayani" ke pengertian yang sesungguhnya. Pelayanan yang seharusnya ditunjukan pada masyarakat umum kadang dibalik menjadi pelayanan masyarakat terhadap negara, meskipun negara berdiri sesungguhnya adalah untuk kepentingan masyarakat yang mendirikannya, birokrat sesungguhnya haruslah memberikan pelayanan terbaiknya 
kepada masyarakat (Kurniawan, 2017). Bukan sebaliknya yaitu meminta dilayani oleh masyarakat yang merupakan paradigma lama dalam pelayanan publik dan acapkali dialami sehari-hari pada saat berurusan dengan pelayanan publik.

Inovasi memiliki aspek yang luas karena dapat berupa pengembang barang maupun jasa, proses, metode pemasaran, atau metode organisasi yang baru atau telah mengalami pembaharuan yang menjadi jalan keluar dari permasalahan yang pernah dihadapi oleh organisasi tersebut. Dalam konteks ini, inovasi yang akan ditunjukkan adalah bagaimana pelayanan PATEN yang sudah ada tersebut dapat dikembangkan dengan mengkontekstualisasikan dengan kondisi saat ini, di mana akses digital sudah semakin mudah dan murah, di tambah dengan kondisi pandemi COVID-19 ini. Artinya, perlu inovasi yang bisa mempermudah akses pelayanan publik bagi masyarakat dengan tetap menjaga kualitas pelayanan publik kepada masyarakat, yang salah satunya dengan memasukan unsur penggunaan teknologi informasi dalam kegiatan pelayanan.

Agar kebutuhan pelayanan administrasi kepada masyarakat dapat dilakukan dengan maksimal meskipun di masa pandemi COVID-19, maka dibutuhkan inovasi pelayanan kepada publik yaitu masyarakat yang berada di sekitar Kecamatan Rambang Kapak Tengah. Inovasi yang dibentuk yaitu pembuatan website bertujuan untuk mempermudah kerja kecamatan dan mempermudah dalam pemenuhan proses layanan adminsitrasi kepada masyarakat.

\section{Governansi digital}

Konsep governansi digital bukan konsep yang baru dalam tata kelola pemerintahan, konsep ini menitikberatkan penggunaan teknologi digital dalam proses penyelenggaraan pemerintah, hal yang sama dalam pemakanaan electronic-government atau e-government yaitu suatu penataan sistem manajemen dan proses kerja di lingkungan pemerintah dengan mengoptimalkan pemanfaatan teknologi informasi dan komunikasi, sehingga konsep governanasi digital dan e-government dapat dimaknai dua hal yang sama namun sedikit berbeda. E-governmant suatu sistem teknologi informasi yang dikembangkan oleh pemerintah untuk meningkatkan pelayanan publik dengan memberikan pilihan kepada masyarakat, untuk mendapatkan kemudahan akses informasi publik agar terwujudnya clean and good governance pada suatu negara (Sari \& Winarno, 2012). Inti dari pendapat tersebut adalah mempermudah masyarakat mendapatkan akses informasi atas pelayanan yang diberikan pemerintah dengan menggunakan teknologi informasi dimana pemerintah sebagai arus utama informasi. Sedangkan governansi digital atau pemerintahan digital merupakan pengembangan dari konsep e-government dengan lebih menitikberatkan pada keikutsertaan masyarakat pada pengumpulan dan pemanfaatan data, di mana pemerintah dan masyarakat memiliki peran yang setara.

Hasil penelitian Sari \& Winarno (2012) menunjukkan, perkembangan sistem e-government di Indonesia secara kuantitas mulai meningkat namun secara kualitas hal ini belum memadai. Agar segi kualitas semakin terjamin mutunya maka dibutuhkan pengembangan dari berbagai sisi diantaranya adalah infrastruktur, kualitas SDM, implementasi, aturan, dan penyampaian informasi yang berkelanjutan dari pemerintah kepada masyarakat secara terbuka. Dengan demikian, tujuan dari pemerintahan yang bersih dan baik dapat dicapai meskipun masih terdapat tantangan lainnya seperti kapabilitas dan 
ABDIMAS: Jurnal Pengabdian Masyarakat Universitas Merdeka Malang

Volume 6, No. 2, May 2021: 290-304

komitmen dari pemangku kepentingan. Secara general terdapat empat konsep interaksi antar pelaku dalam e-government, yaitu: (1) G to C (Government to Citizens); (2) G to G (Government to Governments); (3) G to B (Government to Business); (4) G to E (Government to Employees) (Sari \& Winarno, 2012).

Pada poin pertama menjelaskan interaksi antara pemerintah dengan masyarakat. Masyarakat dapat mengakses berbagai informasi dari pemerintah. Maka timbul keterbukaan informasi kepada masyarakat dan membuat kepercayaan mulai tumbuh. Di sini peran dari inovasi website yang dibentuk untuk Kecamatan Rambang Kapak Tengah menjadi vital. Dengan adanya pembaharuan berita di setiap hari dan penyampaian informasi data dari pemerintah kepada masyarakat membuat masyarakat merasa memiliki wilayahnya dan timbul kepercayaan yang baik.

Dalam poin kedua di bahas mengenai interaksi antar pemerintah. Pemerintah pusat dengan daerah saling bersinergi untuk mengedepankan pelayanan terhadap masyarakat. Pemerintah daerah yang merupakan perpanjangan tangan dari pemerintah pusat harus mengimplementasikan kebijakan yang telah disepakati pusat salah satunya adalah reformasi birokrasi. Dengan adanya pembuatan website Kecamatan RKT maka birokrasi yang selama ini di anggap menyulitkan dan merepotkan masyarakat dapat dilihat sebagai birokrasi yang sederhana dan mempermudah pengurusan administrasi yang dibutuhkan masyarakat.

Selanjutnya poin ketiga relasi antara pemerintah dengan pelaku bisnis. Hubungan pelaku bisnis dan pemerintah diantaranya bisa dalam betuk investasi baik asing maupun lokal. Jika pemanfaatan website dimaksimalkan maka potensi ekonomi wilayah kecamatan dapat dipromosikan lebih luas. maka pebisnis dari daerah lain atau luar negeri dapat melirik dan tertarik terhadap potensi bisnis yang ada di wilayah Kecamatan RKT seperti memaksimalkan ikan, kopi dan nanas yang menjadi produk unggulan daerah.

Terakhir pada poin keempat yaitu hubungan antara pemerintah dengan pekerja pemerintah sehingga timbul rasa saling memiliki. Jika rasa saling memilik telah tercipta maka antara pekerja dengan pemerintah akan melakukan kerjanya dengan maksimal dan penuh dengan rasa tanggung jawab.

Empat poin di atas menjadi landasan penting dalam menjalankan konsep e-government agar dapat terealisasikan dengan baik. Salah satu realisasi e-government ini adalah dengan menggunakan laman website agar sinergitas pemerintah kepada pemerintah lain, masyarakat, pebisnis, dan pekerja pemerintah menjadi saling linier dan bergerak seperti sistem dalam mesin. Jika satu gear roda mesin tidak berjalan dengan semestinya maka akan mengganggu gear roda mesin lainnya. Hasilnya kinerja mesin menjadi tidak maksimal dan cenderung menghabiskan bahan bakar dengan hasil produksi yang minim. Tentu ini menjadi tantangan pemerintah untuk mensinergikan segala sektor stakeholder agar saling membangun dalam kemajuan.

\section{Pelayanan Administrasi Terpadu Kecamatan (PATEN)}

Pelayanan Administrasi Terpadu Kecamatan (PATEN) merupakan penyelenggaraan pelayanan publik di kecamatan yang proses pengelolahannya mulai dari permohonan sampai ke tahap terbitnya 
dokumen dilakukan dalam satu tempat. PATEN menjelaskan bahwa kecamatan bukan hanya berperan sebagai percepatan peningkatan kualitas pelayanan publik, tetapi berperan pula sebagai katalisator guna menciptakan pelayanan prima melalui konsep pelayanan one stop service atau pelayanan satu pintu (Sukarno, 2017). Tujuan dari terbentuknya pelayanan terpadu tingkat ini untuk mempermudah masyarakat dalam mendapatkan pelayanan di kantor kecamatan tanpa harus mendatangi ruangan per ruangan bidang-bidang pelayanan yang dimaksud. PATEN diselenggarakan dengan tujuan untuk meningkatkan kualitas pelayanan dan mendekatkan pelayanan kepada masyarakat. Peningkatan kualitas pelayanan ini terutama terlihat dari aspek waktu dan biaya pelayanan. Lokasi kecamatan jelas lebih dekat dan relatif mudah dijangkau masyarakat bila dibandingkan masyarakat harus ke ibu kota, kabupaten, atau di dinas perizinan satu pintu serta waktu yang diperlukan juga menjadi lebih efisien.

Secara yuridis formal, terbentuknya PATEN ditandai dengan diterbitkannya Peraturan Menteri Dalam Negeri Nomor 4 Tahun 2010 tentang Pedoman Pelayanan Administrasi Terpadu Kecamatan. Peraturan Menteri Dalam Negeri tersebut secara tegas mengamanatkan dan menginstruksikan bahwa target dari implementasi PATEN dalam Bab IX Ketentuan Peralihan pasal 29, bahwa maksimal pada tanggal 15 Januari 2015 di seluruh Indonesia wajib terselenggaranya PATEN. Permendagri tersebut yang menjadi dasar pendelegasian wewenang bupati/walikota kepada camat untuk memberikan layanan administrasi yang diperlukan masyarakat. Dalam praktiknya, PATEN memerlukan beberapa persyaratan yang harus dimiliki oleh pihak kecamatan, seperti yang penulis kutip melalui lama website Kecamatan Pakisaji Kabupaten Malang persyaratan penyelenggaraan PATEN terdapat tiga, yaitu; (1) Persyaratan Substansif; (2) Persyaratan Adminsitratif; dan (3) Persyaratan Teknis.

Persyaratan substantif adalah adanya pelimpahan sebagian wewenang dari bupati kepada camat diantaranya adalah perizinan dan di luar perizinan. Sedangkan persyaratan administrasi merupakan pedoman utama yang harus dilakukan oleh SDM berupa pegawai pemerintahan di kecamatan. Pelayanan harus sesuai SOP yang berlaku sehingga akan memudahkan kegiatan pelayanan. Misalnya, jika masyarakat ingin melakukan pengurusan KTP maka pegawai pemerintahan harus memberikan informasi yang informatif dan tidak berbelit-belit. Dengan adanya website maka masyarakat dapat dengan mudah mempersiapkan segala persyaratan yang dibutuhkan tanpa harus bolak-balik ke kantor kecamatan atau lurah setempat. Selain itu sarana dan prasarana kantor kecamatan harus mendukung seperti tempat tunggu yang representatif dan nyaman serta pelayanan antara ruangan yang memudahkan.

\section{Pembahasan}

Berdasarkan konsep governansi digital untuk mendukung Pelayanan Administrasi Terpadu Kecamatan (PATEN) maka dibutuhkan inovasi pelayanan publik yang tepat sasaran dan semakin mempermudah interaksi antara kecamatan sebagai representasi pemerintah kepada masyarakat. Inovasi pelayanan publik yang dilakukan tim pengabdian kepada masyarakat FISIP Universitas Sriwijaya yaitu membuat website https://kecamatanrkt.kotaprabumulih.go.id/ yang diperuntukkan kepada Kecamatan RKT. Adapun website ini berisi mengenai informasi pelayanan administrasi sehingga masyarakat dapat dengan mudah mengenai informasi layanan yang dibutuhkan sekaligus terintegrasi dengan pusat 
ABDIMAS: Jurnal Pengabdian Masyarakat Universitas Merdeka Malang

Volume 6, No. 2, May 2021: 290-304

layanan ke kelurahan/desa. Selain itu dapat menjadi sarana promosi potensi kecamatan dan media publikasi kegiatan kecamatan.

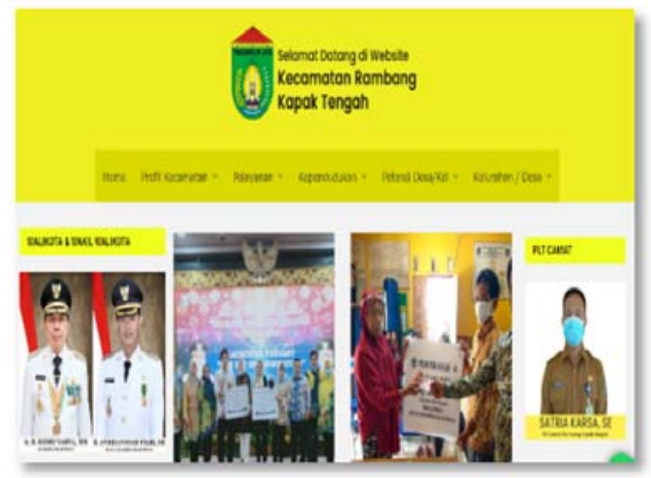

Gambar 5. Laman website Kecamatan Rambang Kapak Tengah sebagai sarana pelayanan publik

Gambar 5 menerangkan hasil inovasi dari tim pengabdian masyarakat FISIP Universitas Sriwijaya beruba website yang dapat digunakan pihak Kecamatan Rambang Kapak Tengah untuk memaksimalkan pelayanan terhadap publik. Maka publik dapat terinformasi dengan jelas apa saja jenis pelayanan yang tersedia dan persyaratan apa yang dibutuhkan dalam mengurus suatu kegiatan administrasi. Selain itu, website dapat digunakan sebagai media informasi dan promosi potensi kecamatan. Maka, masyarakat dan pemerintah dapat berkolaborasi dan bersinergi di era industri 4.0 ini.

Dalam era industri 4.0 saat ini masyarakat sudah mulai memasuki fase digitalisasi sehingga penyampaian konsep governansi digital kepada masyarakat menjadi perlu dan penting agar dapat memanfaatkan fasilitas ini dengan maksimal. Era industri 4.0 adalah penggabungan teknologi digital dengan internet untuk diaplikasikan kepada berbagai bidang industri (Prasetyo \& Sutopo, 2018). Integrasi teknologi digital dengan internet ini kemudian menjadikan kehidupan masyarakat lebih mudah, salah satunya yaitu penggunaan teknologi dengan internet pada pelayanan administrasi oleh pemerintah. Tentu ini membutuhkan dukungan dari pemerintah sebagai fasilitator dan regulator penyelenggara pemerintahan. Konsep PATEN yang menyederhanakan penerbitan suatu dokumen juga membuat konsep governansi digital menjadi penting. Dengan demikian, masyarakat yang membutuhkan pelayanan tidak harus mendatangi banyak pintu sehingga akan memakan waktu, tenaga, dan biaya. Saat ini website kecamatan menjadi hal yang perlu dikembangkan agar konsep PATEN tersebut dapat dilaksanakan dengan maksimal.

Website kecamatan hanya perlu memberikan informasi persyaratan dan pengumpulan data untuk kemudian dilanjutkan kepada bagian-bagian yang sesuai dengan keperluan dari masyarakat. Bagianbagian yang telah diberikan tanggung jawab akan memproses permintaan administrasi tersebut untuk diselesaikan, seperti misalnya pembuatan KTP, akta lahir, akta kematian, surat pindah domisili, surat 
izin usaha, dan lain sebagainya. Hal tersebut menjadi salah satu bagian dari reformasi birokrasi yang didengungkan oleh pemerintah pusat. Maka ada sinergitas yang linier antara pusat dengan daerah.
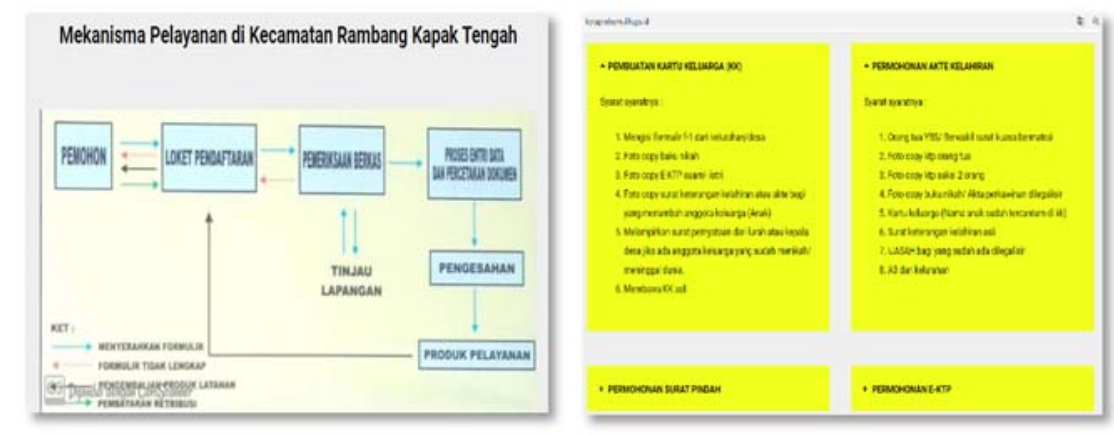

Gambar 6. Mekanisme pelayanan di Kecamatan Rambang Kapak Tengah di website Gambar 7. Informasi persyaratan administrasi di website

Gambar 6 menerangkan bentuk mekanisme pelayanan publik yang dapat dipakai masyarakat sehingga tidak bingung ketika datang ke kecamatan untuk mengurus suatu kebutuhan administrasi. Melalui website yang dibuat maka masyarakat dapat mengetahui apa saja persyaratan yang harus di bawa ketika akan mengurus suatu keperluan di kecamatan dan atau di kelurahan/ desa. Tentu ini menjadi terobosan yang dapat memudahkan pihak masyarakat dan kecamatan/ kelurahan agar kinerja menjadi lebih efektif dan efisien

Dapat terlihat dengan jelas melalui laman website pada Gambar 7 apa saja yang perlu dibawa oleh masyarakat untuk mengurus administrasi sehingga memberikan keterbukaan informasi kepada masyarakat. Namun kedepannya, website ini akan terintegrasi dengan website kelurahan/desa yang ada di Kecamatan RKT karena hampir semua keperluan dan kebutuhan mengenai layanan administrasi masyarakat dilakukan di kelurahan/kecamatan. Dengan adanya portal utama kecamatan ini maka dapat menjadi rumah utama bagi kelurahan/desa. Maka, masyarakat bisa mengurus semua layanan administrasi sepenuhnya dengan daring/online tanpa harus datang ke kelurahan/desa. Tentu program ini menjadi salah satu dukungan terhadap pemerintah pusat mengenai reformasi birokrasi.

Selain penggunaan website kecamatan sebagai inovasi pelayanan administrasi, website juga dapat digunakan sebagai media informasi kepada masyarakat. Dapat menimbulkan keterbukaan informasi kepada masyarakat maka memunculkan kepercayaan dari masyarakat. Selain itu, masyarakat dan pemerintah kecamatan memiliki rasa saling memiliki. Benar kiranya tentang pepatah "tak kenal, maka tak sayang", pembuatan website ini berguna untuk masyarakat lebih mengenal pimpinan di daerahnya. Dengan demikian maka kegiatan pemerintahan dapat dilihat secara langsung oleh masyarakat dan ini menjadi preseden baik. 
ABDIMAS: Jurnal Pengabdian Masyarakat Universitas Merdeka Malang

Volume 6, No. 2, May 2021: 290-304
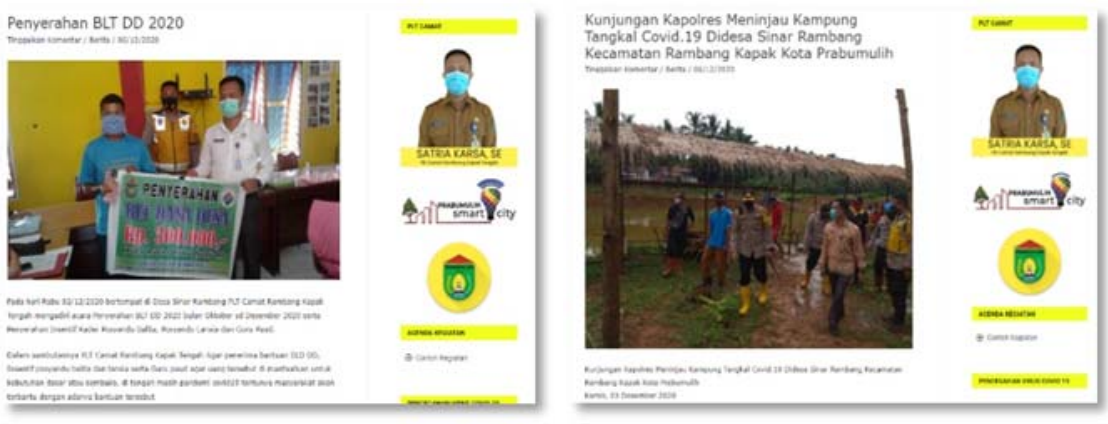

Gambar 8. Penyerahan bantuan BLT kepada masyarakat dari pihak Kecamatan ke Warga

Gambar 9. Kunjungan Kapolres Kota Prabumulih panen ikan patin di Kecamatan Rambak Kapak Tengah

Gambar 8 menggambarkan website kecamatan dapat bermanfaat juga sebagai media informasi kepada masyarakat. Dengan adanya pemberitaan seperti ini maka terwujud transparansi dari pihak pemerintah kepada masyarakat sehingga akan menumbuhkan kepercayaan yang baik. Seperti terlihat pada Gambar 8 adanya penyerahan bantuan BLT dari pihak kecamatan kepada warga, ini menandakan bahwa BLT memang betul-betul tersalurkan dengan baik. Jika ada masyarakat yang tidak mendapatkan BLT maka mereka bisa melakukan pengaduan ke pemerintah.

Maka portal webiste yang dibuat oleh tim pengabdian kepada masyarakat FISIP Universitas Sriwijaya ini juga dapat dimanfaatkan sebagai media publikasi kegiatan kecamatan sehingga masyarakat tahu apa yang dikerjakan oleh pemimpinnya. Selain itu, program ini menjadi salah satu aspek dari transparansi kepada publik atas kegiatan yang dilakukan oleh camat, lurah, maupun kepala desa. Dengan demikian, masyarakat merasa lebih dekat dengan pemimpin dan merasa saling memiliki wilayahnya sendiri.

Website juga tidak terbatas untuk pelayanan administrasi dan media informasi. Selain itu website juga dapat digunakan sebagai media promosi bagi masyarakat yang memiliki UMKM di sekitar kecamatan. Menambah pendapatan bagi masyarakat, tentu ini menjadi pendapatan juga bagi kecamatan dan dapat di kenal secara global. Maka akan menstimulus masyarakat untuk berinvoasi dan berkreasi untuk produk unggulan mereka.

Pada Gambar 9, dapat dilihat bahwa portal website juga bisa jadi kegiatan promosi potensi ekonomi di Kecamatan RKT. Seperti kunjungan Kapolres Kota Prabumulih untuk meninjau kolam ikan patin sekaligus panen. Ini menjadi salah satu cara desa bertahan dari pandemi COVID-19. Tidak terbatas pada pengelolahan kolam patin saja, namun kecamatan ini memiliki banyak potensi lainnya. Jika terus ditingkatkan maka ini bisa mengundang investor untuk memberikan modal kepada masyarakat yang mengelola ikan bioflok dan mendapatkan pesanan yang lebih meningkat lagi di masa depan.

\section{SIMPULAN DAN SARAN}

Berdasarkan penjabaran pada materi sebelumnya maka dapat ditarik kesimpulan jika inovasi pelayanan publik untuk memaksimalkan dan efisiensi kinerja dibutuhkan kerangka konsep governansi digital yang direalisasikan dalam bentuk website kecamatan. Dalam hal ini yaitu website Kecamatan 
Rambang Kapak Tengah, karena sebelumnya Kecamatan RKT belum memiliki website terintegrasi sehingga dengan adanya pembuatan website ini dapat memudahkan kegaitan pelayanan masyarakat, transparansi informasi publik, dan promosi potensi ekonomi kecamatan. Harapannya website ini dapat dikembangkan menjadi lebih variatif dan mendukung segala kegiatan yang bersifat administratif maupun non administratif sehingga penyelenggaraan pemerintah dapat berjalan dengan baik.

Dalam proses pengabdian ini terdapat beberapa keterbatasan kegiatan diantaranya adalah terbatasnya pegawai kecamatan yang memahami teknologi dan pemahaman menulis artikel yang masih kurang. Sehingga perlu adanya pelatihan khusus untuk memberikan keahlian yang lebih baik dari sebelumnya. Selain itu, terdapat kendala sinyal internet yang masih naik turun sehingga dapat menjadi penghambat kelancaran administrasi secara daring. Masih kurangnya sosialisasi secara besar karena terhalang oleh pandemi COVID-19 yang tidak memungkinkan untuk mengumpulkan orangnya banyak dalam hal ini adalah masyarakat luas. Melalui artikel ini penulis memberikan saran kepada pihak Kecamatan Rambang Kapak Tengah agar memberikan pelatihan teknologi dan informasi serta penulisan artikel kepada tim yang mengelola website kecamatan serta pelatihan menulis artikel berita sehingga dapat memaksimalkan penggunaan website. Selain itu, untuk kedepannya penggunaan menu dan detail dalam website dapat ditingkatkan lagi serta melakukan sosialisasi terhadap masyarakat mengenai website agar semua informasi yang ingin disampaikan pihak kecamatan dapat tersalurkan dengan baik. Dalam proses pengabdian ini di rasa masih terdapat kekurangan sehingga penulis berharap kepada penerus atau pengabdi selanjutnya untuk dapat memperbaiki kekurangan fitur dalam website ini seperti pengumpulan data desa yang lebih lengkap, fitur integrasi yang lebih luas dengan kelurahan/desa sehingga website yang telah dibuat ini dapat dimanfaatkan dengan baik dan berkelanjutan.

\section{UCAPAN TERIMA KASIH}

Penulis mengucapkan terima kasih kepada Universitas Sriwijaya atas bantuan baik materil mapun non materil sehingga proses pengabdian dan penulisan jurnal ini berjalan dengan baik dan lancar tanpa terkendala yang berarti.

\section{DAFTAR PUSTAKA}

Aji, R. (2016). Digitalisasi, era tantangan media (Analisis kritis kesiapan Fakultas Dakwah dan Komunikasi menyongsong era digital). Islamic Communication Journal, 1(1), 43-54.

https://doi.org/10.21580/icj.2016.1.1.1245

Faidati, N., \& Khozin, M. (2018). Analisa strategi pengembangan kota pintar (smart city): Studi kasus Kota Yogyakarta. JIP: Jurnal Ilmu Pemerintahan, 3(2), 171-180. https://doi.org/10.24905/jip.3.2.2018.171-180

Hasanah, H. (2016). Teknik-teknik observasi (Sebuah alternatif metode pengumpulan data kualitatif ilmu-ilmu sosial. Jurnal at-Taqaddum, 8(1), 21-46. https://doi.org/10.21580/at.v8i1.1163

Hasibuan, A., \& Sulaiman, O. K. (2019). Smart city, konsep kota cerdas sebagai alternatif penyelesaian masalah perkotaan kabupaten/kota, di kota-kota besar Provinsi Sumatera Utara. Buletin Utama Teknik, 14(2), 127-135. 
ABDIMAS: Jurnal Pengabdian Masyarakat Universitas Merdeka Malang

Volume 6, No. 2, May 2021: 290-304

Kurniawan, R. C. (2017). Inovasi kualitas pelayanan publik pemerintah daerah. Fiat Justisia: Jurnal Ilmu Hukum, 10(3), 569-586. https://doi.org/10.25041/fiatjustisia.v10no3.794

Nurmi, N. (2017). Membangun website sistem informasi dinas pariwisata. Jurnal Edik Informatika, 1(2), 1-6. https://doi.org/10.22202/ei.2015.v1i2.1418

Peraturan Menteri Dalam Negeri Nomor 4 Tahun 2010 tentang Pedoman Pelayanan Administrasi Terpadu Kecamatan

Prasetyo, H \& Sutopo, W. (2018). Industri 4.0: Telaah klasifikasi aspek dan arah perkembangan riset. Jurnal Teknik Industri, 13(1), 17-26. https://doi.org/10.14710/jati.13.1.17-26

Sari, K. D. A., \& Winarno, W. A. (2012). Implementasi e-goverment system dalam upaya peningkatan clean and good goverment di Indonesia. JEAM: Jurnal Ekonomi Akuntansi dan Manajemen, 11(1), 1-19.

Sukarno, D. (2017). Infrastruktur dan teknologi pada kecamatan-kecamatan di Kabupaten Bandung dalam mendukung pelaksanaan program paten (Pelayanan administrasi terpadu kecamatan). Jurnal Manajemen Pelayanan Publik, 1(1), 109-124. https://doi.org/10.24198/jmpp.v1i1.13565

Yanuar, R. M. (2019). Inovasi pelayanan publik (Studi kasus: Public Safety Center (PSC) 119 Kabupaten Bantul sebagai layanan kesehatan dan kegawatdaruratan). Kemudi: Jurnal Ilmu Pemerintahan, $4(1), 1-20$. 